\title{
TRANSFORMATION OF EDUCATIONAL PROCESSES IN THE DONETSK REGION: CONFRONATION OF REALITIES
}

\begin{abstract}
The article observes the transformational processes in educational environment of the Donetsk region and hightights the vectors of pro-European and reverse models of educational processes. The author emphasises on the differences between reformation and indocrination, alanyzes upbringing of the younger generation and necesserity to develop a program of prevention the manipulative methods which influence on the consciousness of youth through the educational channels.

Education of Ukraine has become the prolongation to the Soviet system. Russification and the relics of Soviet values have played a key role in the process of losing of Ukrainian positions in the Donetsk region and Lugansk region. The occupation of these territories lays a deeper diversity in worldvie, because the occupants support the basis of the "Russian world" through education and mass media.

Ukrainian education has gone from deideologization, humanization and national orientation to the European vector of change. The reform of Ukrainian school is aimed at forming an active position of student in the modern world.

The Donetsk region have suffered from a strong russification of schools, which even today demonstrate the lowest rates for teaching on Ukrainian language. The occupied territory of the Donbas is subjected to political and cultural reprogramming of population according to the Russian inrerest. They do it through the educational processes by the way of forced introduction of a pro-Russian model into school curricula.

The processes of indocrination appeared in the purposeful reorientation of teaching courses and program material according to the Russian context. In the content we could see the shifting emphasis, revision of the humanitarian disciplines in the discourse of Slavic (Russian) world restoration.

It is important to develop methodological support and a broad informative basis for responding to a humanitarian attack by a neighboring state.
\end{abstract}

Keywords: education, language, program, reform, indocrination

Широкомасштабна криза на південному сході України, спричинена військовою агресією та окупацією мала свої передумови. Донецький регіон у своєму соціокультурному змісті позиціонував себе окремим френоменом України, апелюючи до ваги індустріального центру з промисловими гігантами та демографрічної насиченості. Проблемність регіону виявилась в часи загострення кризових явищ в економічній та політичній сфері, що яскраво окреслила і гуманітарну дезорієнтацію регіону. Нестійкі проукраїнські тенденції у поєднанні з пострадянською ностальгією, дала можливість переорієнтовувати населення на сусідній російський простір. Цей процес тривав роками через гуманітарно-інфрормаційний простір шляхом збереження рудиментів освіти, маніпуляції інформацією, поступовим пропонуванням альтернативного розвитку.

Освіта незалежної України стала спадкомницею радянської системи навчально-виховного процесу, тому не дивно, що саме російськомовний чинник та прорадянські ціннісні орієнтири, в умовах толерування владою, відіграв ключову роль у втраті українських позицій. Окупація Донеччини та Луганщини на сьогодні закладає ще глибший світоглядовий розкол, адже через освіту та мас-медіа закладає ґрунт «русского мира». Як наслідок існує нагальна потреба поетапного спростування багатьох міфрів, які ширяться через інформаційні канали та вироблення аргументованого знання щодо протистояння чужому світу.

Осмисленням шляхів розвитку пострадянського освітньо-культурного простору займаються чимало сучасних науковців, зокрема Ф. Андрушкевич, Г.
Ягодін, І. Мухіна. Теоретично осмислює сучасну українську педагогіку О. Вишневський.

Гуманітарна сфрера сучасного окупованого Донбасу, зокрема освітній фронт, подається в аналітичних записках та наукових дослідженнях Ю. Вишневського, І. Грідіна, О. Стяжкіної, науковців Національного інституту стратегічних досліджень М. Степико, А. Іщенко. Етнополітичний аналіз Донеччини здійснюють В. Котигоренко. О. Калакура, Л. Ковач,В. Коцур, Н. Кочан, Н. Макаренко, Ю. Ніколаєць, М. Панчук, О. Рафальський.

Окрема сфрера досліджень зосереджується на механізмах маніпуляції суспільною свідомістю, тоталітарними моделями управління державою у роботах А. Михненко, М. Чабанної. Значними у соціологічній науці у питаннях маніпуляцією свідомості та вплив через мас-медіа на суспільну думку є праці американських вчених П.Лазарсфельда і Р.Мертона, що ефективно використовується у сучасних гібридних війнах. Вони дійшли висновку, що ті, хто контролюють погляди і переконання в нашому суспільстві, вдаються менше до фізичного насильства і більше до масового навіювання. Нерідко радіопрограми і реклама замінюють залякування і насильство.

Метою дослідження стали трансформаційні процеси в освітньому середовищі Донецького краю, вплив відторгнення окупованих територій на зміну змісту освітньо-виховного процесу молоді.

Формування освітньої системи України зазнало змін після проголошення незалежності. Руйнування радянської системи супроводжувалося процесами деідеологізації, гуманізації та національній 
зорієнтованості. Радянська модель освіти, яку інституційно успадкувала українська і, яка потребує тривалого часу для реструктуризації, мала ряд особливостей. На думку О. Вишневського: колишня радянська освіта будувалася за принципом унітарності, отже орієнтувалася на навчання і виховання абстрактної «усередненої» людини; традиційно зміст навчання обмежувала поняттями знань, умінь i навичок, а тому переважно лише їх i забезпечувала дітям; колишня освіта була авторитарною - як на рівні управління, так і на рівні процесу едукації, звідси велике значення інспекторів, методистів, керівників шкіл [1].

Європейський вектор реформування української школи повинен бути спрямованим на подолання директивно-патерналістської форми організації освітнього процесу, орієнтуючи учня на активну позицію та має передбачати швидкий технологічний розвиток світу. Це вміння добору інструментарію для аналізу інформації, фрормування критичного мислення, орієнтування у різноманітних життєвих ситуаціях. Це дасть відповідність школи новому соціальному замовленню.

Не менш важливим $€$ аналіз змісту освіти. Адже виховання дітей на замовчуванні історичних фрактів, на ігноруванні українських пріоритетів, на підміні понять конкретних національних інтересів абстрактними глобальними, у критичні моменти призводить до гуманітарної кризи та втрати суверенітету. $\mathrm{Hi}$ русифікація під гаслами «інтернаціоналізму» чи слов'янського «братерства», ні європейська глобалізація не можуть цілком стати змістом нашого виховання. Навіть так зване «радянське» виховання було глибоко національним: воно здійснювалося конкретною національною мовою (переважно російською), будувалося на конкретній національній культурі (переважно російській) і переслідувало цілком конкретні національні інтереси - російської нації [1].

Після проголошення незалежності Кабінет Міністрів України затвердив Державну національну програму «Освіта» («Україна XXI століття») (1993р.) [4], в якій акцентувалося на необхідності «подолання девальвації загальнолюдських гуманістичних цінностей та національного нігілізму, відірваності освіти від національних джерел», відхід від засад авторитарної педагогіки, органічна інтеграція освіти і науки.

Гуманізація освіти передбачає гуманітаризацію змісту навчання - шляхом збільшення частки тих предметів, котрі «репрезентують» людину (історії, літератури, мистецтв, українознавства тощо), органічний зв'язок 3 національною історією, культурою, традиціям, національне виховання. Вагомого значення в цей час для виховання патріотизму та поваги до своєї батьківщини вченийпедагог А.Г. Погрібний надавав вивченню українознавства як комплексу дисциплін, і виділення ії̈ як окремої дисципліни [12, с. 60].

Дана проблема зачіпає мовне питання в освіті. Радянська влада, дотримуючись політики «злиття націй», «двомовності», «мови міжнаціонального спілкування» стимулювала процес русифрікації української школи. Обстоювалася так звана «теорія боротьби двох культур», з якої випливало, що, оскільки російська культура в Україні пов'язана 3 прогресивним пролетаріатом і містом, у той час як культура українська - 3 відсталим селянством і селом, то російська культура рано чи пізно переможе [6, C.120].

Нерівноправне становище української мови порівняно $з$ російською значною мірою закріпила постанова ЦК КПРС від 31 червня 1978 р. «Про подальше вдосконалення вивчення й викладання російської мови в союзних республіках», що визначала виділення додаткових асигнувань на підготовку підручників і програм з російської мови та літератури у школах, технікумах, вищих навчальних закладах, збільшення годин на ії викладання, створення нових періодичних видань. Також з 1984 р. було передбачено збільшення посадових окладів на $15 \%$ учителям підготовчих та $1-3$ класів, які здійснюють навчання російською мовою, вчителям російської мови та літератури 4-11 класів шкіл та шкіл-інтернатів усіх типів із національною мовою навчання, розташованих у сільській місцевості, селищах міського типу. У результаті цілеспрямованої урядової національно-мовної політики в 1986/1987 навчальному році порівняно $з$ 1955/1956 р. питома вага учнів у школах з українською мовою зменшилась з 72,8\% до 40,6\%. Лише $24 \%$ дітей, охоплених дошкільною формою виховання, відвідували дитячі садки і групи з українською мовою [8].

На момент здобуття Україною незалежності лише 49.3\% школярів України навчалися українською мовою. У часи незалежності наша держава поступово відновлює рідну мову викладання у школах і у 2012 році українською навчалось 81,9\% учнів країни. Найнижчі показники по навчанню українською мовою як на початок незалежності, так i на сьогодні були в Криму 0\%, Донецькій області 3,3 \% та Луганській 6,7 \%. До 1999 року не більше 0,5\% в Криму, 10 \% в Донецькій і 13\% учнів в Луганській областях були охоплені українською мовою викладання. 32005 по 2012 рік спостерігається позитивна, достатньо активна динаміка українізації шкіл, яка в Криму дала показник 7,8 \%, Донецькій $48,3 \%$ і Луганській - 48,1 \% [14].

Катастрофою для Донецького регіону стала окупація частини земель. Весь Східний регіон України лихоманило від провокативних захоплень держбудівль, які супроводжувались проросійськими сепаратистськими гаслами. В значній мірі це було випробування на опірність старим доктринам, спроби вирватись від тиску маніпулятивних технологій, новий етап підтвердження суверенності.

Сучасна межа окупованих територій виникла внаслідок військового протистояння, в регіоні вона не відобразила ні етнічних анклавів, ні мовнокультурного порубіжжя. Загалом весь регіон тривалий час знаходився в ситуації гуманітарної та 
економічної кризи, з відсутністю чіткої орієнтації на український центр та поширенням ідей регіоналізації. Населення по обидва боки прифронтової зони ментально, соціально, економічно мало одинакові характеристики. Які ж процеси залишились спільними, а які можуть кардинально розмежувати населення, в тому числі і етнічно.

Системні державні структури, функціонування інституцій, навчальні заклади, органи соціального забезпечення та економічні процеси після 2014 року були переорієнтовані на Росію, хоча не спричинили культурного шоку серед населення. Стан воєнного положення i підсилених каральних операцій забезпечили безпомічність людини, страх опору, силового впровадження змін. Ескалація конфлікту донині відбувається через поглиблення прірви між ідеалізованим російським проектом та маніпуляційно поданим українським. В ситуації нестійкої ідентичності існує небезпека протистояння двох реальностей, 3 образами ворогів, етнічними чистками, військовим протистоянням.

Очевидно гуманітарна криза на окупованих територіях вдало описується процесом індокринації. За визначенням О. Лісничука В «Політичній енциклопедії» індокринація - це «некритичне сприйняття соціальними суб'єктами пропонованих ззовні ідей», «цілеспрямоване впровадження тих чи інших політичних ідей для формування певної суспільної свідомості». Стан індокринації означає результативну реалізацію програми «вживлювання» тієї чи іншої доктрини в суспільну свідомість, може відбуватись як через жорсткі методи тиску на психологію громадян (залякування, примус, погрози), так і через м'які (переконання на привабливих образах, заохочення тощо) [10].

Виходячи з радянського минулого, мешканці регіону 3 малою долею опору піддаються індокринації, адже повертаються в ситуацію досвіду життя в тоталітарній державі. Одним 3 ефективних каналів індокринації $€$ освітні та виховні процеси, які трансформують свідомість нового покоління.

Після початку окупації, за даними Уповноваженого Президента України з прав дитини, на кінець 2014 року на окупованих територіях Донбасу залишалося близько 500 тис. дітей, з них майже 6 тис. дітей-сиріт і дітей, позбавлених батьківського піклування. Понад 160 тис. дітей виїхали 3 Донбасу в інші регіони України. Із проблемою продовження навчання у вищих навчальних закладах Донбасу зіткнулися близько 150 тис. студентів [8, с.180-181]. На початок 2015 року на окупованих територіях Донецької та Луганської областей проживало в чотири рази більше дітей, ніж виїхало на територію, контрольовану Україною. Отже, основна маса дітей залишилась на території, що перебуває під окупацією [5]. За неофіційними даними збільшилась кількість повернень вимушених переселенців з дітьми, тому кількість дітей на тимчасово окупованих територіях у 2016 - 2017 році могла зрости.
Розглядаючи події, пов'язані з окупацією значної частини Донецького регіону, можна припустити, що місцеве населення, діти та молодь зокрема, попало в умови системного соціокультурного експерименту, пов'язаного 3 світоглядною переорієнтацією на імперський конструкт - «русский мир», що синтезував у собі радянські та імперські символи, конструкції «повернення-воз'єднання» російської спадщини. Попри те, що Росія не спішить офріційно брати на сій баланс ці території, все ж за тактикою гібридної війни чітке програмування населення проти всього українського та долучення до «цивілізаційних переваг» всього російського, сформує тривалий образ ворога-України, на розвінчування якого піде багато часу.

Що ж забезпечує обґрунтування та дає можливість існування уявних держав? Це конструювання ідейних догм, претензії на події історичної давнини, що як доктрина відтворюються 3 ідеологем російсько-імперського та радянського минулого. Подібна схема мімікрувала в систему освіти самопроголошених утворень, виконуючи ідеологічні і пропагандистські завдання.

Насамперед, окупаційна влада взяла курс на русифрікацію та фактичне знищення україномовної освіти. Фактично мовне питання стало подразником політичної ситуації та підставою окупації українських територій під гаслом захисту «русскоговорящих», відповідно відбувся реверс щодо україномовної освіти. В перший період 2014 р. при загальному спрямуванні у навчанні на російську мову, «республіки» ще визначались чи потрібні взагалі такі предмети, як українська мова й література. У новостворених російських класах навчання проходило по українських програмах 3 російською мовою викладання, але підручники були на українській мові. В січні 2015 року окремі школи та класи з українською мовою викладання примусово перевели на російську. А в травні цього ж року батьків змушували писати заяви про їхнє бажання, щоб у наступному навчальному році діти навчались російською мовою. Українська мова також виключена 3 іспитів, за відсутності «бажаючих її здавати». За інформацією на сайті так званого «міністерства освіти «ДНР», у 2015/16 навчальному році співвідношення російських та українських класів становило 97\% до 3\% [9]. Таким чином вернувся показник радянського періоду. Разом з тим, утверджена Концепція «Філологічна освіта: Русистика» на п'ятирічку 2016 - 2020 рр., яка надає пріоритетне сприяння російській мові, культурі, літературі з метою ліквідації перегинів мовної політики на Донбасі, подолання спотворення та непротидії націоналістичним інтерпретаціям історії [2]. На Луганщині викладання української все частіше переводиться на факультатив. Там формально можна вибрати будь-яку мову, а на практиці з батьками ніхто не радиться. Є зміни і у програмі української мови та літератури. Загалом виділяється лише 18 годин протягом навчального року [3]. 
Процеси індокринації виявилися у цілеспрямованій переорієнтації курсів викладання i програмового матеріалу на російський контекст. У програмах зміщено змістові акценти, відбувається перегляд гуманітарних дисциплін для відновлення «аури слов'янського світу». Зокрема, у школах на непідконтрольній українському уряду території «вичистили» будь-яку згадку про Україну відбувається видалення символів з підручників та класів, правових норм і свят України, також забороняється визнання України Батьківщиною (з 2014 року як рекомендація прибрати тему «Україна наша Батьківщина»).

У даних процесах можна простежити певну етапність - від ситуативних змін у викладанні дисциплін по українських підручниках до щорічного підпорядкування російським програмам. Зокрема, спочатку в початковій школі 2014 - 2015 рр. навчання велося за українськими програмами, Історія України замінювалася регіональною дисципліною «Донецькознавство», «Суспільствознавство», суперечливі теми переносились у друге півріччя; згодом історія України змінилася на «Історію Донецького краю», «Історію вітчизни» або просто «Історію».

Згідно держстандарту на 2015 - 2017 рр. змістове наповнення програм так званої «ДНР» у п'ятому класі («Вступ в історію Донеччини») передбачає акцент на краєзнавство, тематику козацтва подає лише через зв'язок з донськими козаками, робить акценти на входження території Донеччини у Російську державу, ДонецькоКриворізьку республіку, охоплює звитяги радянського періоду і викреслює незалежну Україну.

Викладання історії у 6-9 класах реалізується в рамках двох курсів - «Історія Отєчества», який складається 3 «Історії Росії» та «Історії Донеччини» та «Всесвітньої історії». Основним завданням основоположного для гуманітарних наук курсу $€$ виховання патріотизму та вивчення історичного досвіду народу ДНР і всього людства. Очевидно, через історію Росії робиться спроба легітимізувати неіснуючу спільність «народ ДНР» у світовій історії. Якщо проаналізувати програми 7, 8, 9 класів за 2014 - 2017 рр., то помітний процес русифрікації, що йшов від посилення окремих тем про Московське царство чи Російську імперію (2014р.) до повного ігнорування історії України. Зокрема, запорізьке козацтво подається лише в контексті донського, війна під керівництвом Б.Хмельницького в складі Речі Посполитої в програмі 2015 р. ще згадується, хоч і подається на вибір вчителя, а вже у 2017 році розглядається в контексті Переяславської угоди, реформи 1861 р. подаються через Донецький регіон, акцентується увага на соціал-демократичні структури в регіоні, а громадівський рух розглядається як малоросійський. Загалом. предмет зорієнтований на детальне вивчення російської історії, з синхронним поданням історичних особливостей «пограничного» статусу Донецького регіону. При цьому акценти робляться на формування централізованого Московського царства, переростання його в імперію, а 32017 р. чіткіше окреслюється самодержавний мотив через вивчення теорії офіційної народності С. Уварова, яка закріплює формулу «православ'ясамодержавність-народність». Не уникається можливості подати антиросійську спрямованість українського руху, наприклад через творчість М.Міхновського та Ю.Бачинського [13].

На Луганщині подібний комплект програм доповнено новим предметом, «Основи православної культури» для 3-4 класів, щодо викладання якого і в Росії точаться дискусії.

За словами педагогів, які залишилися на окупованій території Луганщини, усі учні початкової школи «ЛНР», на 2016 р повністю переведені на російські освітні програми і стандарти. «Міністерство освіти і науки ДНР» дало неофіційну команду готуватися до переходу на російські вимоги щодо організації навчального процесу. Це стосується співвідношення годин на різні цикли дисциплін, формування навчального навантаження тощо [12]

Така масова переорієнтація спричиняє потребу перекваліфікації вчителів на викладання російської мови або звільнення з роботи і виїзд на підконтрольну українському уряду територію.

Поряд з російською мовою як головне завдання «міністерством освіти ДНР» визначено військовопатріотичне виховання у рамках ініційованої «міноборони республіки» «програми шефрства військових над школами».

Що чекає молоде покоління по обидва боки фронту через кілька років? Очевидно кардинальні розбіжності у світоглядах та різна ідентичність. Необхідно врахувати, що освіта на українських територіях також не стоїть на місці. Сучасні процеси реформування зорієнтовані на європейську освіту 3 акцентом врахування компетентностей, необхідних для успішної самореалізації особистості [11], прийнято новий Закон України «Про освіту» (2017р.), відбувається громадське обговорення програмового матеріалу. Окрім того, реалізуються декомунізаційні закони, які прагнуть очистити українську історію та топоніміку від радянських символів.

Протилежними $€$ завдання керівників окупованих територій, адже їх основним ідейним скріплюючим чинником $є$ не європейське майбутнє, а радянське минуле 3 його героями та символами. Будь-які зміни в Україні в національній риториці активно відстежуються і коментуються окупаційною владою 3 метою денаціоналізації українського гуманітарного простору, подання його як «антирусского проекту», ворожого до місцевого населення.

Необхідним для освітянської громадськості в Україні на сьогоднішній день $€$ врахування різних способів поширення концептів «русского мира», що через розроблені ідеологеми впливають на молоде покоління. Важливим $€$ розроблення методичного супроводу та широкої інформативної бази щодо 
реакції на гуманітарну атаку з боку сусідньої держави, що є стратегічним пріоритетом держави. Необхідно враховувати, що учні на окупованих територіях, які почали формувати власну ідентичність у незалежній Україні матимуть певну опірність до маніпуляції фактами, тому варто шукати найбільш ефективні методи взаємодії з ними для залучення до українських освітніх процесів.

Таким чином, освітнє середовище Донецького краю за останні пів століття зазнало ряду трансформацій - від тотальної русифікації та ідеологізації радянського періоду до часткової українізації в мовному питанні та гуманітаризації навчального процесу, яке внаслідок територіального поділу сформувалось як різновекторні проекти освіти. Шкільна програми українського підпорядкування прямує шляхом європеїзації, а освіта окупованих територій запрограмована на російський простір з прорадянськими та проімперськими рудиментами. Проблемність такого розколу буде очевидною в процесі реінтеграції даної території в Україну.

1. Бабич Л. Остался ли украинский язык в школах на оккупированной части Донбасса? // Радіо Свобода [Електронний ресурс]. - Режим доступу: https://www.radiosvoboda.org/a/28742810.html

2. В ДНР приступают к реализации Концепции «Филилогическое образование: Русистика» [Електронний ресурс]. - Режим доступу: https://dnronline.ru/v-dnr-pristupayut-k-realizacii-koncepcii-

filologicheskoe-obrazovanie-rusistika/

3. Вишневський О.І. Теоретичні основи сучасної української педагогіки. - К.: «Знання». 2008. - 568 с. [Електронний ресурс]. - Режим доступу: http://tourlib.net/books_others/vyshnevsky.pdf

4. Державна національна програма «Освіта» (Україна XXI століття). - К. : Райдуга, 1994. - 61 с.

5. Діти війни: дослідження проблем дитинства в Україні за умов військової агресії // Український інститут дослідження екстремізму. [Електронний ресурс].- Режим доступу

http://uire.org.ua/doslidzhennya/1738/

6. Донбас в етнополітичному вимірі. - К. ІПіЕНД імені І.Ф. Кураса НАН України, 2014. - 584 с.

7. Донбас і Крим: ціна повернення : моногр. / за заг. ред. В. П. Горбуліна, О. С. Власюка, Е. М. Лібанової, О. М. Ляшенко. - Київ : НІСД, 2015. - 474 c.

8. Історія України. Мицик Ю. А., Бажан О. Г., Власов В. С. Навчальний посібник. - Київ: Видавничий дім «Києво-Могилянська академія». 2008. [Електронний ресурс].- Режим доступу : http://www.ebk.net.ua/Book/history/mitsyk_iu/annotatio n.htm

9. Кущ Л. Школи "ДНР": як вивчають українську історію і мову? [Електронний ресурс]. // ВВС Україна - Режим доступу: http://www.bbc.com/ukrainian/society/2016/10 /161026_ukrainian_in_donetsk_om
10. Лісничук О. Індоктринація // Політична енциклопедія. Редкол.: Ю. Левенець (голова), Ю. Шаповал (заст. голови) та ін. - К.: Парламентське видавництво, 2011. - с.287

11. Про схвалення Концепції реалізації державної політики у сфрері реформування загальної середньої освіти "Нова українська школа" на період до 2029 року // Освіта.UA [Електронний ресурс].

Режим доступу: https://osvita.ua/legislation/Ser_osv/54258

12. Погрібний А. Розмови про наболіле, або Якби ми вчились так, як треба. - К.: Просвіта, 2000. $-320 \mathrm{c}$.

13. Рабочие программы [Електронний ресурс]. - Режим доступу: http://school123.ucoz.net/index/ /rabochie_programmy/0-41

14. Частка учнів у школах України, що навчаються українською // Карти виборів 2014 [Електронний ресурс]. Режим доступу:

http://statistika.in.ua/mova2001/ukrainska_v_shkolah

\section{References:}

1. Babych L. Has the Ukrainian language remained in schools in the occupied part of Donbass? Radio Svoboda [Online] Available from: https://www.radiosvoboda.org/a/28742810.html [Accessed: 18th September 2017].

2. In the DNR they begin to implement the Concept "Filial Education: Russian Studies» [Online] Available from: https://dnr-online.ru/v-dnr-pristupayut-krealizacii-koncepcii-filologicheskoe-obrazovanierusistika/ [Accessed: 24th February 2016].

3. Vyshnevskyi O.I. (2008). Theoretical foundations of modern Ukrainian pedagogy. Kiev. $568 \mathrm{p}$ [Online] Available from: http://tourlib.net/books_others/vyshnevsky.pdf [in Ukr.]

4. State National Program "Education" (Ukraine XXI century). (1994) Kiev: Raiduha, 61 p. [in Ukr.]

5. Children of war: research of children's problems in Ukraine in conditions of military aggression // Ukrainian Institute for the Study of Extremism [Online] Available from: http://uire.org.ua/doslidzhennya/1738/ [Accessed: 10th June 2015].

6. Donbas in the ethnopolitical dimension (2014). Kiev: IPiEND the name of I.F. Kuras NAN Ukrainy, 584 p. [in Ukr.]

7. Donbass and Crimea: the price of return: monohr. / red. V. P. Horbulina, O. S. Vlasiuka, E. M. Libanovoi, O. M. Liashenko (2015). Kyiv: NISD, 474 p. [in Ukr.]

8. History of Ukraine. (2008) Mytsyk Yu. A., Bazhan O. H., Vlasov V. S. Tutorial.- Kyiv: Vydavnychyi dim «Kyievo-Mohylianska akademiia». [Online] Available from: http://www.ebk.net.ua/Book/history/mitsyk_iu/annotatio n.htm

9.Kushch L. Schools "DNR": how do you learn Ukrainian history and language? BBS Ukraina [Online] Available from: http://www.bbc.com/ukrainian/society/2016/10/161026_ 
ukrainian_in_donetsk_om [Accessed: 27th October 2016].

10. Lisnychuk $O$. Indocrination. In: Political encyclopedia. (2011). Redkol.: Yu. Levenets, Yu. Shapoval. - Kiev: Parlamentske vydavnytstvo, 287 p. [in Ukr.]

11. On Approval of the Concept of Implementation of the State Policy in the Field of General Secondary Education Reform "New Ukrainian School" for the Period till 2029. Osvita.UA [Online] Available from:
https://osvita.ua/legislation/Ser_osv/54258 [Accessed: 14th December 2016].

12. Pohribnyi A. (2000)Talk about painful, or If we were learning how it should be. - Kiev: Prosvita,. - 320 p. [in Ukr.]

13. Work programs [Online] Available from: http://school123.ucoz.net/index/rabochie_programmy/0-41 14. The share of Ukrainian students studying in Ukrainian. [Online] Available from: http://statistika.in.ua/mova2001/ukrainska_v_shkolah

Удк 377 (477)

\title{
Олена Газізова
}

\section{ПРОБЛЕМИ ЕТНОКУЛЬТУРНОГО ПРОСТОРУ АР КРИМ В КОНТЕКСТІ АНЕКСIÏ ПІВОСТРОВА}

\begin{abstract}
Анотація. В системі етнокультурних взаємин в АР Крим ключове місце посідає кримськотатарська проблема, зумовлена як низкою успадкованих від минулого факторів, так і недосконалістю законодавчої бази України, ї етнонаціональної політики. Сформована за роки незалежності політико-правова база створила підгрунтя для гармонійного поєднання інтересів усіх складових української політичної нації, однак вона недостатньо забезпечила рівні умови для етнонаціонального розвитку й активної участі у державотворчих процесах кримськотатарського народу та національних меншин.

За даними Всеукраїнського перепису населення України 2001 р., в Автономній Республіці Крим проживало 24,3 \% українців, 58,3\% - росіян, 12,0\% - кримських татар, 5,4 \% - інших національностей, зокрема, білорусів - 1,4 \%, татар 0,5 \% та ін. Окрема статистика по місту Севастополю свідчить про переважання російського населення (71,6 \%), майже середньостатистичний по Криму відсоток українців (22,4 \%) та про нечисельну кримськотатарську громаду $(0,5 \%)$.

За роки незалежності національно-культурні потреба українців і кримських татар задовольнялися вкрай погано. Так, з 583 шкіл, що фрункціонували у Криму в 2014 р., лише 7 були україномовними, а з 23,4\% школярів - етнічних українців - державною мовою навчалися лише 0,7 \%. У 2013/14 навчальному році рідною мовою здобували освіту 5551 кримськотатарська дитина, національно-культурні потреби кримських татар не задовольнялися повністю, кількість навчальних місць в кримськотатарських класах не відповідала реальним потребам. Однією з причин такої ситуації була відсутність кваліфікованих педагогічних кадрів, недостатнє забезпечення навчальною літературою тощо.

Після анексії Криму українська мова, яку окупаційна влада визнала однією із державних, майже повністю зникла з освітнього простору Криму, із 7 шкіл з українською мовою навчання залишилась тільки 1. У Республіці Крим продовжує фрункціонувати 15 загальноосвітніх закладів з кримськотатарською мовою навчання (201 клас, 3651 учень).

Виклики в гуманітарній сфері, зокрема упосліджене становище української мови в культурно-освітньому континуумі Криму, задовго до початку збройного конфрлікту на сході України та анексії АР Крим знаходилися у полі зору української гуманітаристики, провідні науковці вказували на негативні етнокультурні тенденції, викликані бездіяльністю органів державної влади, що підсилювали загрози дезінтеграції та втрати державного суверенітету. За роки незалежності України в Криму не було сформовано сильного проукраїнського електорату, здатного до відстоювання державного суверенітету. Враховуючи постійну підтримку Росією російської громади півострова, лобіювання ідеї «руського мира» та «исконно русского Крыма» і недостатню підтримку Україною української та кримськотатарської громад, які здатні були б протистояти сепаратистським загрозам, ідеологічна війна на теренах Криму була програна ще до 2014 р., що стало однією з причин анексії півострова.
\end{abstract}

Ключові слова: національна культура, АР Крим, анексія, українці, кримські татари, росіяни, гуманітарні виклики.

\section{Olena Hazizova}

\section{PROBLEMS OF ETHNOCULTURAL SPACE OF THE AR OF CRIMEA IN THE CONTEXT OF THE ANNEXATION OF THE PENINSULA}

Annotation. The Crimean Tatar problem holds a leading position in the system of ethnocultural relations with the AR of Crimea. It is caused by a number of factors inherited from the past, as well as by the imperfection of the legislative basis of Ukraine, its ethnonational policy. Political and legal foundation, built during the years of independence, made it possible to combine the interests of all components of the Ukrainian political nation; however, it didn't provide equal conditions for the ethnonational development and active participation in state-building processes of Crimean Tatars and national minorities.

According to the All-Ukrainian Population Census of 2001, the ethnic composition of the Autonomous Republic of Crimea is as follows: Ukrainians constitute $24.3 \%$, Russians $-58.3 \%$, Crimean Tatars $-12.0 \%$, other nationalities - $5.4 \%$ (Belarusians $1.4 \%$, Tatars $-0,5 \%$, etc.). Separate statistics regarding the city of Sevastopol indicated the prevalence of Russians (71.6\%); almost the statistically average percentage of Ukrainians in Crimea (22.4\%); and a small Crimean Tatar community (0.5\%).

During the years of independence, the national and cultural need of Ukrainians and Crimean Tatars to study in their mother tongues was extremely poor. So, out of 583 schools that functioned in Crimea in 2014, only 7 were Ukrainian, and from $23.4 \%$ of ethnically Ukrainian schoolchildren only $0.7 \%$ were taught in the state language. In the 2013-14 academic year, 5551 Crimean Tatar children were educated in their native language; the national-cultural needs of the Crimean Tatars were not completely 